\title{
Should Accounting Majors Have Human Resource Training in Compliance, Coaching, Team-Building and Mentoring Skills?
}

\author{
Linda Flaming \\ Monmouth University \\ Joseph Mosca \\ Monmouth University
}

This paper looks at the human resource skills of legal compliance, coaching, team building and mentoring that would be useful for accounting students entering the work place. It begins by briefly describing these areas and illustrating how a lack of knowledge could impact an accountant's success. It then shows how the accounting profession recognizes the need for these "interpersonal skills". Finally, it provides suggestions on how these skills could be incorporated in accounting programs or curriculum and illustrates how students themselves can gain exposure to these skills through online professional websites (e.g., www.aicpa.org) that provide some knowledge in the areas mentioned to better prepare graduating accounting students for the accounting profession.

Keywords: Accounting, Human Resources, Interpersonal Skills, Soft Skills

\section{INTRODUCTION}

The world of accounting has changed rapidly. Students preparing for a career in accounting must look beyond the basic accounting knowledge of accounting rules and regulations and must be able to function successfully in a global business environment. Often, firms look for a mix of technical and soft skills (Brumfield 2017) and spend as much or more time looking at the candidates' soft skills, including corporate fit, communication and collaboration skills, and leadership ability (McCann 2017). They consider the candidate's ability to persuade, solve problems, and influence both internal and external customers.

The American Institute of Certified Public Accountants (AICPA) has been addressing these issues, identifying and promoting a list of related skills essential in today's environment. These skills include critical thinking, problem solving, analytical ability and professional skepticism, effective communication skills, strong research skills, an understanding of the business environment and processes, and ethics and professional responsibilities, (Gallagher, 2015). In addition, the AICPA's list of professional competencies includes ethical conduct, professional behavior, decision-making, collaboration, leadership, communication and project management (AICPA 2018c).

Yet these skills are often lacking in recent college graduates. Charlton (2007) notes the additional challenges to an already overloaded management, because the preparation of recent graduates are not up 
to levels needed by corporations. Fundamental writing skills needed to communicate effectively in the workplace are lacking and there exists a definite gap between what employers want and what graduates are taught (Caprino 2016). Employees at all levels in all professions ae required to write reports, work instructions, emails and other forms of communication. Thus, the ability to express oneself using wellconstructed sentences, free of grammatical errors is a desirable trait. Other interpersonal management skills are also lacking. Xavier (2007) points out that more emerging leaders lack the fundamental skills to manage people effectively. In addition to communication skills, emotional skills are becoming critical to success. Awareness of feelings, empathizing with others, and assessing how these feelings and emotions affect relationships and business decisions is essential.

Due in part to this challenge, corporations must now re-educate employees in everything including the basics. The average annual training expenditure per employee in 2004 was $\$ 955$ and jumped to $\$ 1,424$ in 2005 (Tai 2006). She goes on to note that the 2006 State of The Industry report by the American Society Of Training And Development (ASTD) estimates organizations spend approximately $\$ 109.25$ billion annually on workplace learning and performance (WLP).

The accounting profession is no exception. Most firms and the AICPA acknowledge that many related hard and soft skills are lacking in recent accounting graduates. Hoffelder (2018) enumerates both technological and soft skills (e.g., communication) skills that are lacking in accounting graduates. Robert Half Associates (2016) reports that 54\% of chief financial officers give equal weight to specialized and soft skills when hiring, and that soft skills are more important as you move up the ladder. In a Wall Street survey of 900 executives, $92 \%$ said soft skills were more important than technological skills, and $89 \%$ cited difficulty in finding candidates with those skills. (Davidson 2016).

One researcher interviewed several human resource personnel and leaders at small CPA firms in a major metropolitan area and confirmed the need for human resource related soft skills in entry-level accountants (Gardner, Mayer, and Chen 2018). This paper focuses on the benefit of human resource skills to those entering the accounting profession, categorized into four areas of legal compliance, coaching, team building and mentoring. These areas encompass many of the skills iterated above (communication and collaboration, decision-making and leadership as examples). This paper illustrates how the lack of essential human resource skills could be a hindrance in the accounting profession, describes the types of skills human resource training could provide, and finally assesses how the profession is dealing with the need for such skills. It concludes by suggesting ways to incorporate training in these skills in a business accounting curriculum (or through other professional development means).

\section{ILLUSTRATION}

Take the example of Pat, who had completed a BS in Accounting with a strong GPA and had passed the Uniform Certified Public Accountant (CPA) exam on the first attempt. Pat's collegiate training did include many of the related areas mentioned above, including courses in information technology, ethics, communications, research and critical thinking. With these strong accounting and soft skills, a major accounting firm quickly hired Pat.

Pat's first 12 months performance proved the firm made the right choice. At first, Pat's strong technical knowledge, motivation and willingness to help others gained Pat the reputation of a team player. Pat was soon promoted to senior status and Jules, Pat's supervisor, felt confident placing Pat in charge of a small group of audit personnel, some of whom had years of experience with the firm but were not CPAs. Jules had minimal contact with Pat once Pat assumed the new position.

Thus, Jules was surprised when receiving two separate complaints against Pat for two separate instances. In one case, Pat was cited in a letter from an attorney claiming an employee wanted to press Disparate Treatment charges against the firm because of Pat's discriminatory actions toward an older employee. This charge stemmed from an employee claim of being treated differently from others based on age, race religion, or gender (Denisi-Griffin, 2011). It turns out that while training a group of employees to use a new computerized audit program, Pat separated the team into two groups based on age, stating that "since you older members will take longer to train, I will begin your training first." 
Although Pat was trying to be helpful and assure all employees received proper training, the approach did not comply with HR practice.

The other complaint was about a violation of the Americans with Disabilities Act. The complaint arose when Pat assigned team members to physically count merchandise in a large warehouse during an audit. Intending to be objective, Pat chose to assign team members randomly to different sections of the warehouse, where merchandise stored on shelves six to twenty feet high. When assigning the audit team to the locations, Pat did not consider the physical environment nor the employees' skills, qualifications and abilities, and had arbitrarily assigned a four-foot, nine-inch tall audit assistant (with two fused spinal vertebra) to audit merchandise on a high section of shelves. If Pat had been familiar with the American Disabilities Act (ADA) and its workplace protections and provisions, this situation could have been avoided.

Pat and supervisor, Jules were both required to attend a mediation hearing along with the affected employees to resolve the issues. Fortunately, everyone agreed that none of these acts were malicious but simply oversight.

Additionally, employees brought up more intangible concerns about how Pat tended to patronize the team members who were not CPAs, and how Pat did not utilize the knowledge and experience of the other team members. The mediator's solution was to recommend that Pat attend awareness training for (1) legal compliance, (2) employee coaching, (3) team building and (4) mentoring, to avoid any future misunderstandings, the first training session she attended was employee coaching.

The remainder of the paper describes how these aspects of Human Resource training can benefit those entering the accounting and auditing profession and related fields, and ways in which those entering the accounting field might gain these skills.

\section{ASPECTS OF HUMAN RESOURCE TRAINING}

\section{Legal Compliance}

Accountants are well aware of the need to meet numerous legal compliance requirements. Public company financial statement preparers must adhere to United States Generally Accepted Accounting Principles (Financial Accounting Standards Board 2010), tax accountants must adhere to the Internal Revenue Service (IRS) codes, while auditors must follow Generally Accepted Auditing standards (Public Company Accounting Oversight Board (PCAOB) 2002). Would knowledge about human resource compliance issues be useful too?

\section{Americans with Disabilities Act}

Today's accounting professionals commonly assume interpersonal management roles, whether within the firm itself (e.g. leading an audit team) or externally (consulting and advising clients). Therefore, an understanding of workplace compliance is expected. Pat's required training consisted of exposure to the Americans with Disabilities Act (1990). The ADA prohibits discrimination based on disability and all aspects of the employment relationship such as job application procedures, hiring, firing, promotion, compensation, and training, as well as other employment activities such as advertising, recruiting, tenure, layoffs, and leave and fringe benefits. The most recent amendment in 2008 broadens the protection offered to persons with disabilities at work by defining certain disabilities as "presumptive," thus negating several court cases that had ruled certain persons having disabilities as not qualifying for coverage under ADA (Denisi and Griffin 2008).

More specifically to Pat, the terms of the ADA define performing manual tasks, seeing hearing standing, and bending while working (Monday and Martocchio 2016). Had Pat been aware, Pat could easily have considered the employee's physical restrictions when assigning manual tasks.

\section{Workplace Diversity}

Another area of concern is the make-up of our workplaces. Today's organization typically consists of employees from several different generations, cultures, and gender identities, each with their own needs, 
values and approaches to work. Women have entered the workplace in increasing numbers, along with a vast number of immigrants, including those with various sexual orientations (Schumpeter 2016; Pfau, 2016). Although employees within a firm have a fair amount in common, during the past few years the differences they possess have created tension. Therefore, attending to diversity is a fact of business around the world.

In some aspects the accounting profession feels that the use of similar, converged accounting standards might mitigate some of the compliance issues (e.g., "accounting is the language of business", and international converged standards put everyone on the same page). However, there are many other aspects of communication and compliance involved in business. Additionally, the global focus of many accounting firms, like Pat's firm in the illustration, could lead to additional differences that need to be addressed.

\section{Employee Coaching}

With the advent of advanced electronic capabilities, accountants now "come out from behind the desk" and are more involved interacting with people, increasing the value of interpersonal skills (Margaritis, 2016). Coaching in athletics is about helping the athlete reach his peak performance. The same is true within firms. Peak performance is achieved through the building block process. Coaches help the athlete improve performance and managers can do the same by coaching employees to meet objectives. Both Pat and Jules benefited from learning coaching techniques. Keep in mind that managers plan, direct, and control while carrying out the management process. Coaches are seen as developers because they provide daily training and feedback. Coaching enables employees to see the alternative behaviors to what they are currently doing. The prime elements of coaching are feedback, goal setting, and providing guidelines.

Coaching as opposed to managing could be the wave of the future. According to Kiechel (1991), the term "Boss" is a part of the past, with its Neanderthal images of brutish bosses, ordering subordinates around and chewing out employees. Back in the eighties, the new terminology of a "Leader", a "visionary" manager with "transformational abilities" still connotes that the employees are followers. Professor J. DuBrin (2017) at Rochester Institute of Technology stated: "People have more respect for a coach than they do for any other authority figure, perhaps it's because athletics are so deified in our culture." Betsy Wiesendanger (1995) describes how, as organizations downsized and restructured, new management theories became popular (time and motion, reengineering, total quality management, business psychology)

Today's managers can learn a thing or two from a good coach in order to develop efficient teams of employees. Upper level management must consider viewing management issues from a human resource perspective, and help managers to council and coach employees. According to Lukaszewski (1988), the human resource perspective is for the organization to develop managers who are complete thinkers, leading to employee retention. A complete thinker never identifies a problem without offering options and solutions. A complete thinker should have the ability to identify, describe and interpret, forecast outcomes, recommend, and then test specific ideas, regardless of the problem or situation. Effective coaching entails more than merely providing data and facts, it requires volunteering information, stepping aside and being available for assistance. In today's marketplace, successful organizations incorporate cooperation among all their disciplines. Coaching requires a great deal of employee development and counseling. The coach must be able to give and receive feedback, focusing on positives, not negatives. Contemporary managers no longer view employees as mere human capital and therefore have modified their role of commanding bosses or supervisors to supportive coaches who, influence, empower, and establish work teams for their employees, (Hassell 2015). When the coaching method is used frequently, employees learn at a better rate from experiences gained while being coached. Employees are more apt to ask for assistance in the informal coaching time frame of being coached (Grote 2016).

The role of the coach is one who sets goals and assists employees to grow and improve their job competence to reach desired performance levels. The coach helps the employee implement performance plans by providing praise, constant counseling, and constructive criticism when applicable. Coaches 
should be aware of employees' competencies, be available to discuss areas of improvement, encourage and motivate, and review the employees own plans for advancement (Shore and Bloom 1986). The coaches' main objective is always be there when needed, to spot weaknesses, encourage, and motivate. This is accomplished when the coach is engaged on a day-to-day basis using the following components:

\section{Clarifying the Expected Performance}

This component is a part of the job competence cycle and begins with the identification of important aspects relating to the employees' job. At this stage it becomes critical to clarify the expected performance levels for important jobs and related tasks. Use of a written job description at this point becomes helpful for job analysis and clarification of standards. The job description not only describes important aspects of the job but includes what needs to be done. A good coach would use standards that have been established and accepted by both coach and employee. All the mentioned processes are part of a good evaluation of job performance.

\section{Developing Employees}

Managers can create satisfied, productive, and knowledgeable work teams, by engaging in development activities. Why? Employees actually learn to perform better in the work place and then want to assume positions of greater responsibility, benefiting the individual employee and the organization. However, employee development is an ongoing process. It has been found that employee development programs can strongly influence career growth and on the job performance. The proposal here is to use coaching as a development strategy (Shore and Bloom 1986).

\section{Team Building}

Human resource awareness enhances team building when coaching. At one time or another, most employees have worked in an organization and have been a member of a task-performing team. Organizations have come to realize that relying on team-based arrangements can help to improve quality, productivity, customer service, and enhance to work skills of employees (Thompson 2004). Effective teams are not a matter of luck. They are the results from hard work, careful planning, and good coaching. Teams require a thorough understanding of what must be done, when it needs to be done, and who can get it done.

Employees (especially trainees) are usually intimidated when getting to know each other when meeting for the first few times. A good team-building approach is to spend time promoting cohesion by allowing employees to openly discussing their individual core values, and how do they define sense of job commitment (Farnell 2016). Team members who feel comfortable with each other have a higher level of trust among each other and their functionality at goal achievement, because they feel safe with each other which holds the team together (Hughes, 2016).

Organizations, no matter what size or make-up should not feel they can just jump into a team-based culture. Within the small and medium enterprise (SME) it becomes even more critical that management work together towards the strategic plan with a direct financial impact. It will take a combination of solid incentives and a teaching program to give employees the requisite skills needed for success (Davidson 2016). Today's leadership is less about the power of one person and more about collectively the wisdom of many (Ferrazzi and Gatti 2007). Top management must be willing to relinquish the long held centralized power and authority they have as management and workers venture out to create or become part of functional teams. The self-directed work team can become the foundation for a much stronger and more innovative corporation in today's globally competitive market.

Both Pat and Jules benefited from training on how to build a team environment at their workplace. The work term team needs a formal definition best described as a small number of employees who are in pursuit of a common goal to which they hold themselves mutually accountable. Work team development begins with selecting members for the team who are interested and qualifies in similar activities, and those who have enjoyed being part of a team previously. To develop successful teams, Dubrin (2017) suggests: 
- Having a constructive purpose.

- Including a competitive aspect.

- Developing a teamwork culture that suggests working together effectively is an organizational norm. For example, referring to all employees as team members.

- Engaging all employees in the decision making process

- Avoiding micromanagement, by not supervising too close and hampering team spirit, to assure that team members feel empowered.

- Allowing team members to train offsite, experience challenges as an individual and then return to the team.

- Using virtual technology (e.g., interaction with other teams and members via computers) to sharing problem solving issues

Managers should realize that differences show up in almost every facet of management-employee relationship, including the chain of command. For instance, while some workers prefer a traditional approach and are happy to follow process and procedure and do not mind the controlling styles of military management, many employees work best independently and prefer management to collaborate with them in teams rather than micro-manage.

\section{Mentoring}

Many organizations of the $21^{\text {st }}$ century have employed the mentoring concept, by setting up formal arrangements whereby established senior employees assist novices by exposing them to learning the ropes to avoid the pitfalls. This facilitates performance, career advancement, while establishing role models that others look up to (de Janasz and Peipert 2015). Mentors can also assist employees develop specific skills especially when outside of one's comfort zone such as the use of specific technologies, awareness of other disciplines, and how to enhance one's skill sets (Korkki 2016).

In the case of Pat, Jules could have avoided some of the pitfalls by mentoring Pat through the to consider the legal compliance aspects of the job, and overseeing Pat's initial interpersonal relationships to facilitate a coaching, team building approach. And, by being mentored, Pat would be more aware of the mentoring process to share with others.

\section{HUMAN RESOURCE SKILLS IN THE ACCOUNTING PROFESSION}

Human resource skills are considered more and more frequently in numerous accounting publications and forums. The American Institute of Certified Public Accountants (AICPA) website includes a list of professional competencies accounting professionals should have. They iterate such skills as ethical conduct, professional behavior, decision-making, collaboration, leadership, communication and project management.

The Journal of Accountancy (published by the American Institute of Certified Public Accountants) often addresses the need for human resource related skills in their publication. In a Journal of Accountancy article, Brotherton (2000) specifically suggests that CPA's add human resources (HR) training to the mix of for their employees can provide, and even suggests CPA's can be an HR resource to their clients. Even more recently, Gervasi and King (2016) write about the intersection of HR and accounting and a CPA.com article proposed that accountant should be prepared to advise clients on HR.

More and more often, recent trade journal articles address the need for human resource related skills. Tysiac and Drew (2018) focus how understanding processes, communicating well and analyzing data are all part of succeeding in the tech-oriented aspects of accounting. Blitz (2015) describes the successful implementation of teamwork within an accounting firm by encouraging effective cross communication 
technologically and personally. Courtney Vien (2016) describes coaching programs instituted a major CPA firms that help encourage and develop leadership and applies the concept to smaller firms as well. Meyer (2017) described the implementation, success and obstacles to establishing a mentoring program at an accounting firm. Knowledge of team-work is also considered essential (Blitz 2015). Vollmer (2017) intertwines coaching and mentoring techniques, as well as cultural diversity sensitivity when describing how women and minorities were encouraged to advance at a Midwest accounting firm. Levychin (2018) stresses the importance of awareness of other cultures in reaching and obtaining clients and stresses the need for intentional practice to develop intercultural communication skills and sensitivity.

Firms themselves have adopted human resource concepts and training in their corporate culture. In many cases, new employees are assigned a mentor, or coach, to educate new hires into the corporate culture and help the new employees set goals (McCarthy 2015). McCarthy also notes the "higher order" skills that are now being tested on the CPA exam, and suggests that students and graduates themselves are responsible for gaining these new skills to enhance the CPA exam performance and their career.

\section{SUGGESTIONS TO DELIVER HUMAN RESOURCE SKILLS TO ACCOUNTING STUDENTS}

This paper also proposes that human resource training, knowledge and awareness could be part of the enhancing "soft skill" sets for graduating accounting and other business majors, to more fully prepare them for the realities of today's workplace.

One option would be for a specific course in human resources be included as part of an accounting and/or business curriculum. A human resource course could also be included as a free elective to enhance an accounting student's preparation in these desired areas. Such courses would provide training and consideration of the topics mentioned above of legal compliance, coaching, team building and mentoring. A third way would be to integrate human resources consideration within existing accounting course through outside assignments and/or case studies. This might be especially appropriate in an accounting capstone class, where the accounting knowledge, technological skills and interpersonal skills are brought together. In an interview in the Harvard Business Review, Scott DeRue, University of Michigan Ross School of Business dean, cites his and other MBA programs that embed field case studies in their programs. In these programs, students network with actual companies and students from different schools and cultures within the programs so that students graduate with experiences in team building, collaboration and mentoring (Nickisch 2018). Accounting courses could include a capstone where business liaisons and mentoring is developed.

Additionally, during their academic career, students could be encouraged to take the initiative themselves to further develop their soft skills through professionally provided training. The American Institute of Certified Public Accountants (AICPA) has acknowledged the need for these skills and is working to address these issues. They established the AICPA Legacy Scholars program in 2011, which awards students a one-year scholarship to develop skills such as leadership and communication through on campus initiatives (AICPA 2018c)

There are also several online options for accounting students and entry-level accountants to enhance their soft skills. The AICPA offers free membership to students and their website provides a number of webcasts and initiatives that address the need for many of the soft skills iterated in this paper. For instance, legal compliance issues are addressed in a series of webcasts and initiatives on diversity and inclusion (AICPA 2018b). The AICPA also has an online mentoring program to help accountants enhance their soft skills (AICPA 2018a). They also have a section that lists "professional competencies" to make aspiring accountants aware of the soft skills needed (AICPA 2018d).

The AICPA has also established a "ThisWaytoCPA.com" site (AICPA 2018e), with extensive information for students preparing for careers in accounting. Under the education heading, they describe 
preparing for the CPA exam and tell about the Legacy Scholarship Program. The heading entitled Exam describes the exam itself. The Work Experience title includes skill development links, including the soft skills describes in this paper (developing soft skills, technology skills, and more). Their video library has information on the career, the CPA exam, interview skills, skills required in the profession, etc. Students could and should be encouraged to make use of this site.

State societies, too, have programs and information to help students transition and provide mentoring programs for students and entry-level accountants. For instance, the New Jersey Society of CPAs (https://njcpa.org), besides describing the exam requirements, and offering scholarships, has a tab about starting your career, with articles and resources. An example of one such article describes the problem solving and technical skills required for work at a small firm (Ovaska-Few, 2017).

\section{CONCLUSION}

In conclusion, this paper suggests that in today's marketplace, the accounting profession has expanded beyond technical accounting skills. Soft skills such as critical thinking, problem solving, professional skepticism, and teamwork are judged as important (and sometimes even more important) than basic accounting rules and knowledge. Accounting students and entry level accounting professionals could benefit from training and experience in aspects of human resources, such as legal compliance, coaching, team building and mentoring to enhance these essential skills and experience. The paper also suggests that accounting students can gain some of these skills through a dedicated human resource course, through embedded cases and exercises in accounting courses, or through seeking this training on their own through professional organizations and online sources, to enhance their career potential.

\section{REFERENCES}

American Institute of Certified Public Accountants (AICPA). (2018a). AICPA Mentoring. Retrieved from https://www.aicpa.org/career/mentoring.html

American Institute of Certified Public Accountants (AICPA). (2018b). Diversity and Inclusion. Retrieved from https://www.aicpa.org/career/diversityinitiatives.html

American Institute of Certified Public Accountants (AICPA). (2018c). Legacy Scholars Program. Retrieved from https://www.aicpa.org/search.html?source=AICPA\&q=legacy+scholars

American Institute of Certified Public Accountants (AICPA). (2018d). Professional Competencies. Retrieved from https://www.aicpa.org/interestareas/accountingeducation/resources/accountingcore-competencies-personal.html

American Institute of Certified Public Accountants (AICPA). (2018e). This Way to the CPA. Retrieved from https://www.thiswaytocpa.com/

Americans with Disabilities Act of 1990, Pub. L. No. 101-336, 104 Stat. 328 (1990)

Blitz, A. (2015). Teamwork in the Accounting Firm. Accounting Today. Retrieved from https://www.accountingtoday.com/news/teamwork-in-the-accounting-firm

Brotherton, P. (2000). CPAs Add HR to the Mix. Journal of Accountancy, 190(4).

Brumfield, S.M. (2017). Are You a Leader? Strategic Finance, (Feb), 21-22.

Caprino, K. (2016, August 19). A Guy 15 Years Younger Than Me Is Now My Boss-What Do I Do? Leadership if Only I Knew. Forbes.

Charlton, R. (2007). Experiential classroom learning for sport management students: preparing them for the real world. VAHPERD Journal, 29(2), 43+. Academic OneFile, Retrieved May 16, 2019.

Davidson, K. (2016, October 4). Soft Skills Give Workers a Big Edge. The Wall Street Journal.

De Janasz, S., \& Peiperi, M. (2015). CEO's Need Mentors Too. Harvard Business Review, (April).

Denisi, A., \& Griffin, R. (2008). Human Resource Management. Nashville, TN: South Western Publishing, 36-37.

Dubrin, A. (2017). Human Relations: Concepts, Applications and Skills. New York, NY: Pearson Publishing, 336-339. 
Farnell, R. (2016). How U.S. Army Basic Training Turns Diverse Groups into Teams. Harvard Business Review, (July 18).

Ferrazzi, K., \& Gatti, L. (2007). The Human Element of Successful Training. $T+D$, 61(6), 68-72.

Financial Accounting Standards Board (FASB) ASC-105-10-10-1 Generally Accepted Accounting Principles.

Gallagher, R (2015). Maintaining the Relevance of the Uniform CPA Examination. Presentation delivered at the NJCPA Educators Meeting, October.

Gardner, T., Mayer, R., \& Chen, W. (2018). The Important of Soft Skills Training for Accountants. Working paper presented at the AAA MidAtlantic Conference, May.

Gervasi, S., \& King, S. (2016, June 1). The Intersection of HR and Accounting. Strategic Finance. Retrieved from https://sfmagazine.com/post-entry/june-2016-the-intersection-of-hr-andaccounting/

Grote, D. (2016, September 30). Every Manager Needs to Practice Two Types of Coaching. Harvard Business Review.

Hassell, D. (2015). Management 2.0: Coaching Employees in The New Economy. The Blog, Huffington Post, (May 16).

Hoffelder, K. (2018). Accounting Students Lack Hard and Soft Skills After Graduating. Retrieved from http://njcpa.org/stay-informed/topics/article/2018/04/18/accounting-students-lack-hard-and-softskills-after-graduating

Hughes, B. (2016, May 13). Building Better Teams. The Blog, Huffington Post.

Kiechel, W. (1991). The Boss as Coach. Fortune, 124(4), November.

Korkki, P. (2016, September 10). How Could I Possibly Learn from a Mentor Half My Age? Business Day, The New York Times,

Levychin, R. (2018). Why your CQ is Just as Important as your IQ (and EQ). Journal of Accountancy. Retrieved from https://www.journalofaccountancy.com/issues/2018/feb/cultural-intelligence.html

Lukaszewski, J. E. (1988). Behind the Throne: How to Coach and Counsel Executives. Training and Development Journal, 42(October).

Margaritis, P. (2016). Improv is No Joke, Using Improvization to Create Positive Results in Leadership and Life. Retrieved from https://petermargaritis.com/category/communication/page/5

McCann, D. (2017, March 2). Hire Expectations. CFO.com.

McCarthy, S.F. (2015). 12 "Threshold Concepts" Accounting Graduates Need to Know. Retrieved from https://njcpa.org/stay-informed/topics/article/2015/10/09/12-threshold-concepts-accountinggraduates-need-to-know

Meyer, C. (2017). From Wallflower to confident leader. Journal of Accountancy. Retrieved from https://www.journalofaccountancy.com/issues/2017/aug/kimberly-hardy-cpa-mentoringprograms.html

Monday, W., \& Martocchio, J. (2016). Human Resource Management. New York, NY: Pearson Publishing, 100-03.

Nickisch, C. (2018). The Future of MBA Education. Harvard Business Review. https://hbr.org/ideacast/2018/02/the-future-of-mba-education

Ovaska-Few, S. (2017, July 18). What Smaller Firms Expect from New Accounting Grads. Retrieved from https://www.aicpa.org/interestareas/accountingeducation/newsandpublications/newaccounting-graduates-at-small-cpa-firms.html

Pfau, B. (2016). What Do Millennials Really Want at work? The Same Thing the Rest of Us Do. Harvard Business Review, (April 7).

Public Company Accounting Oversight Board. (2002). Responsibilities and functions of the independent auditor. In General auditing standards, (AS 1001). Retrieved from https://pcaobus.org/Standards/Auditing/Pages/AS1001.aspx

Robert Half Finance \& Accounting. (2017). CFOs Seek Finance Professionals with Mix of Hard and Soft Skills. Investment Weekly News, (Oct 8)

Schumpeter, J. (2016, February 13). Diversity Fatigue. The Economist. 
Shore, L. M., \& Bloom, A.J. (1986). Developing Employees Through Coaching. Personnel Management, 63(August).

Tai, W. (2006). Effects of training framing, general self-efficacy and training motivation on trainees' training effectiveness. Personnel Review, 35(1), 51-65. doi.org/10.1108/00483480610636786

Thompson, L. (2004). Making the Team. New Jersey: Pearson, Prentice Hall, pp. 3-7.

Tysiac, K., \& Drew, J. (2018). 4 Skills Accountants Need to Succeed in A Tech-Enable Future. Journal of Accountancy. Retrieved from https://www.journalofaccountancy.com/issues/2018/jun/technology-skills-for-accountants.html

Vien, C. (2016). Coaching Programs Get New Partners Off to A Great Start. Journal of Accountancy. Retrieved from https:/www.journalofaccountancy.com/issues/2016/feb/cpa-firm-coachingprograms.html

Vollmer, S. (2017). How to Sponsor Diversity in the Leadership Ranks. Journal of Accountancy. Retrieved from https://www.journalofaccountancy.com/issues/2017/jan/diversity-in-leadershipranks.html

Wiesendanger, B. (1995). Business Psychology. Journal of Business Strategy, 16(1), (January- February). 